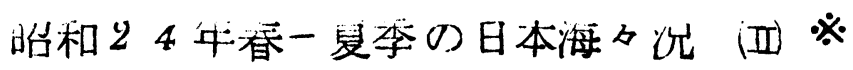

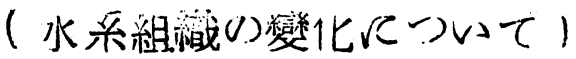

（日本海冲合調查報告ＩI）

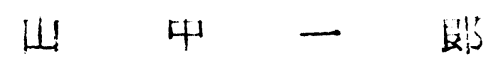

(I)

1. 前報に於ては對馬海流に沿ふて生ずる暧水塊及び椧水塊の移動消长ててついて論じたが，

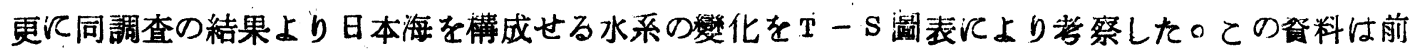
報と同じく各府縣水武の協力により得たてとを明記し，本稿作成に指尊を與へられし宇田道隆， 木村喜之助兩博士，作圆計算浓協力された山中文子，奥原秀子の諸氏に謝意を表する。

\title{
2. $\mathbf{T}-\mathrm{S}$ 曲楾の其本形式
}

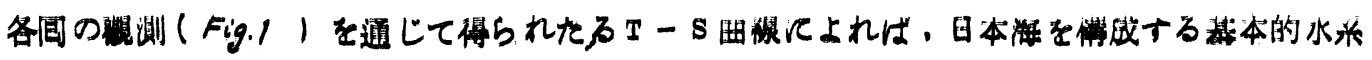

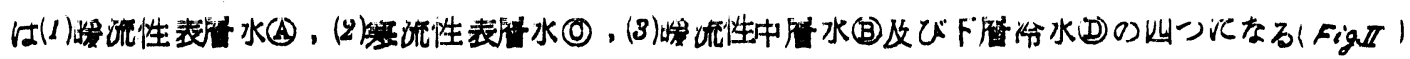

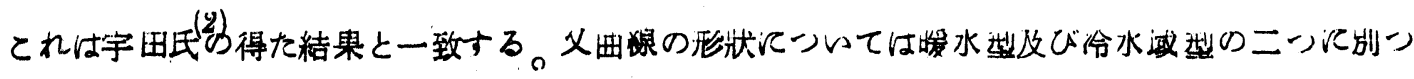

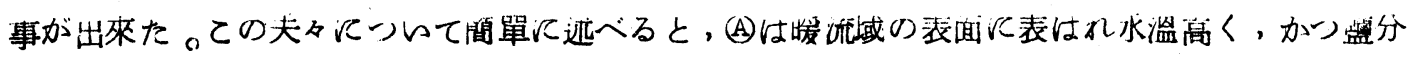
は低く兒にはC2<18.5

となる。间は對馬海流 の根幹をなすのであ つて最高䍄て $\mathrm{Cl}>$

19.0 万至 192 (D) 政び

(1)は篦分は相似て居り $\mathrm{Cl}=18.8$ 内外であり

○は表厤にあるため温 度の變化を受け易いが (D) 沙所誈日本海沽有水 㙕であうて溫度2度内 外で殆ど一定, かつ大 體 $200 \mathrm{~m}$ 以染化现的

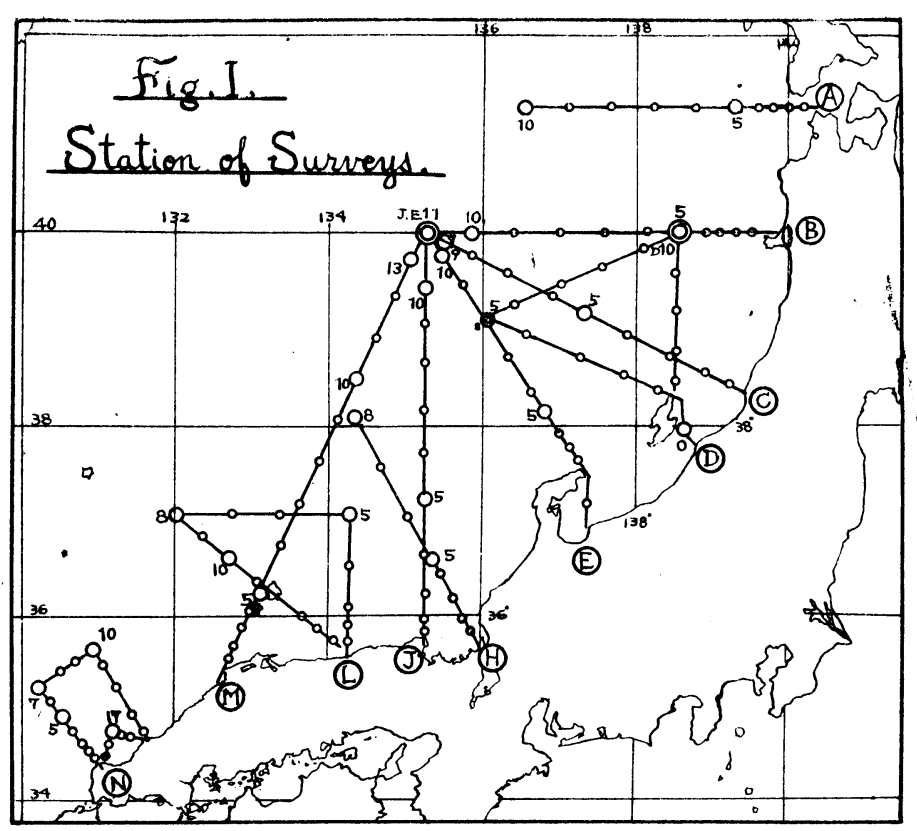
るとと岋よ知られて

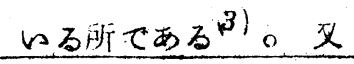

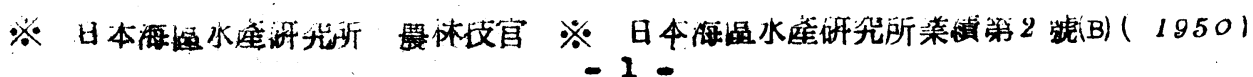




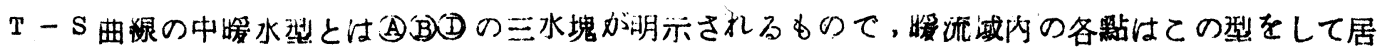

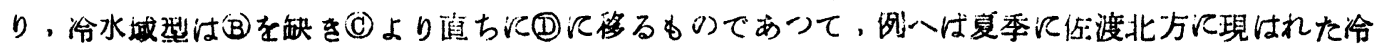

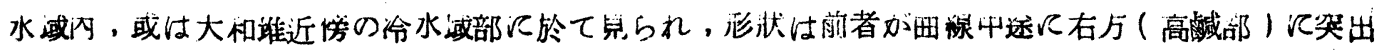

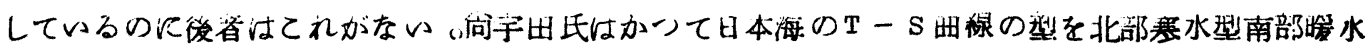

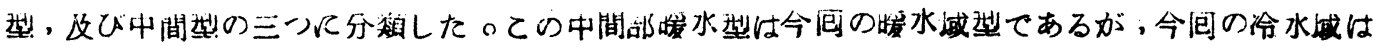

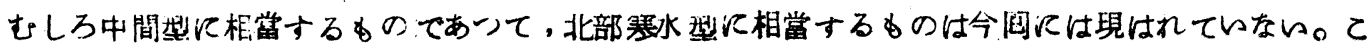
れ江調查游域が日本海北牛に改んていないためでらう。

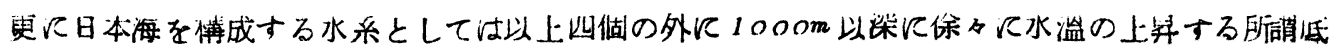
$(4 i$ 增水加あるが今间の誠侐では策度がそて迄及んでるない。

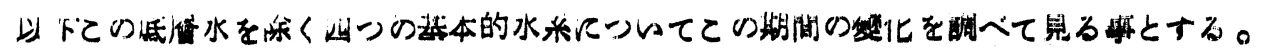

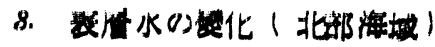

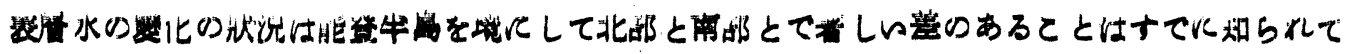

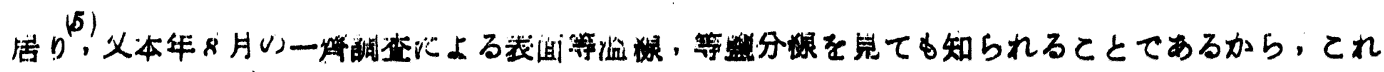

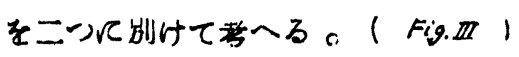

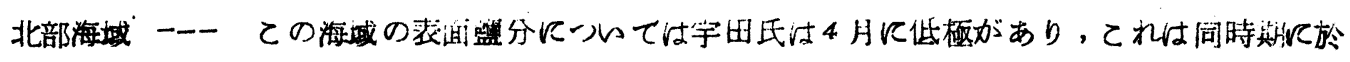

\section{Fig.II. Foundamental Water-mass Composition} of Japan Sea (Aug.1949)
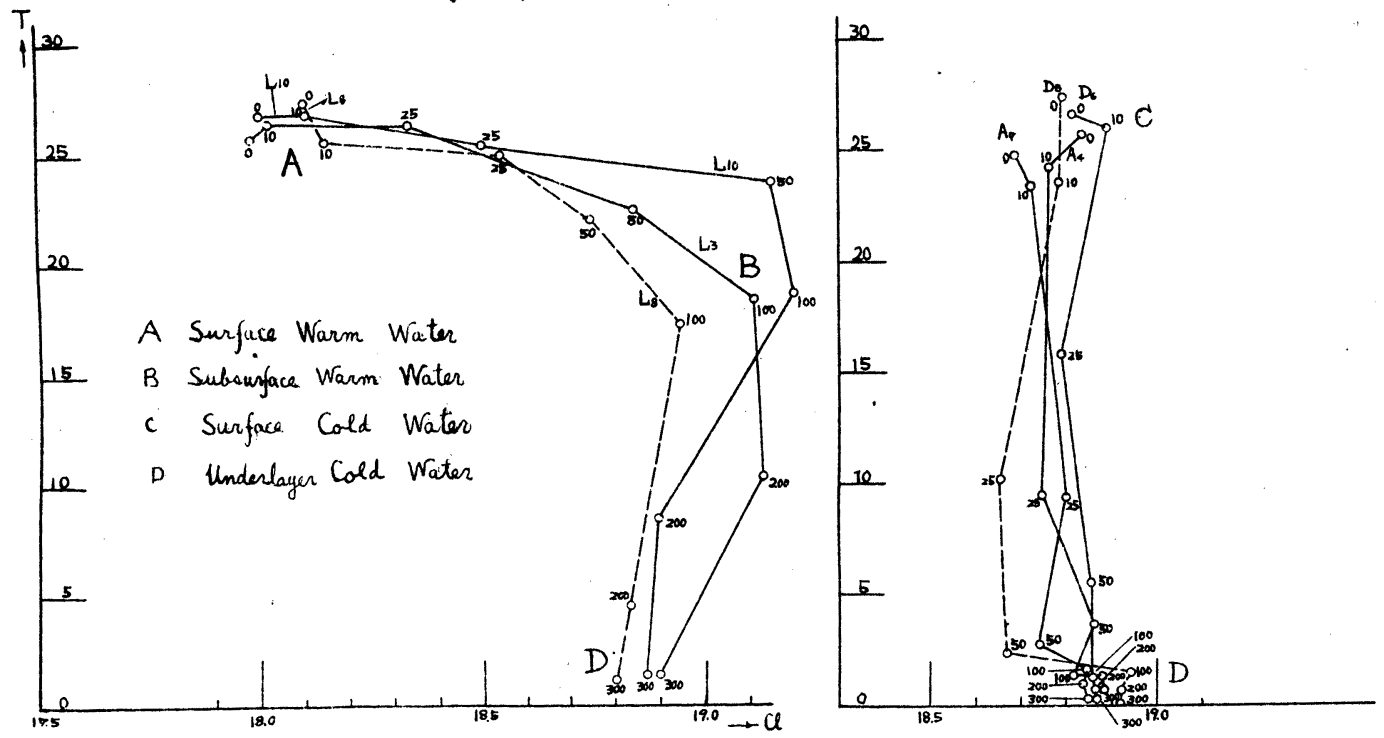


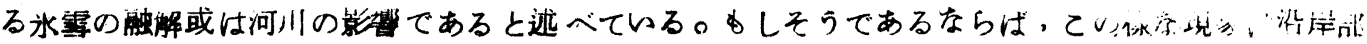

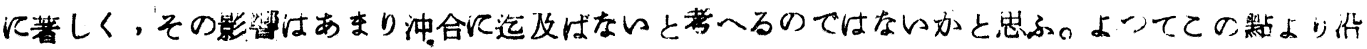
㞥近此離點と也點を比較して見る。

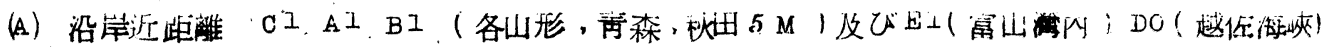

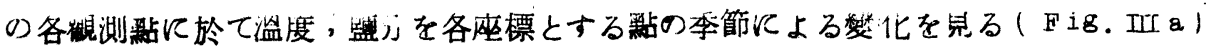

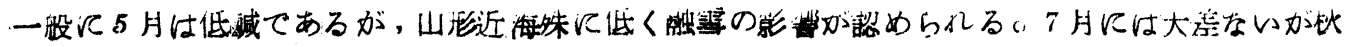

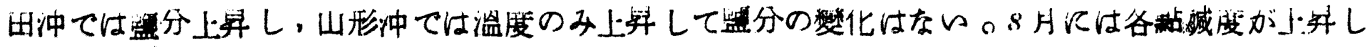

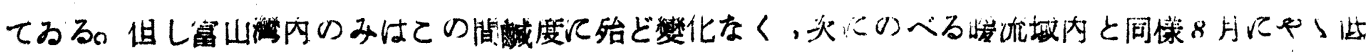

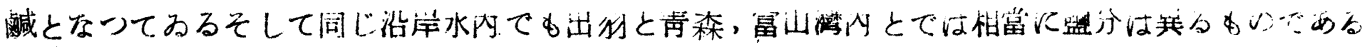

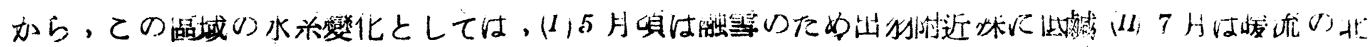

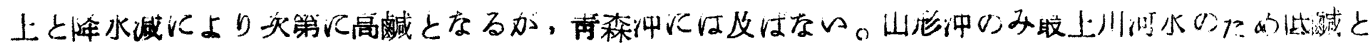

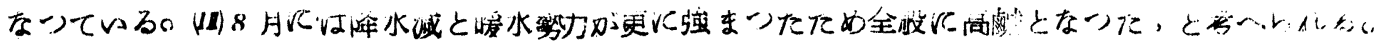

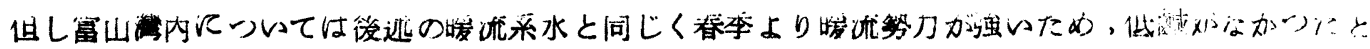
考へられる

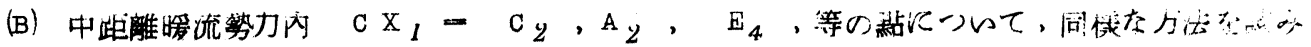

\section{Fig. III. . Sensmal Change of Surface Water. SNathen Pert?}

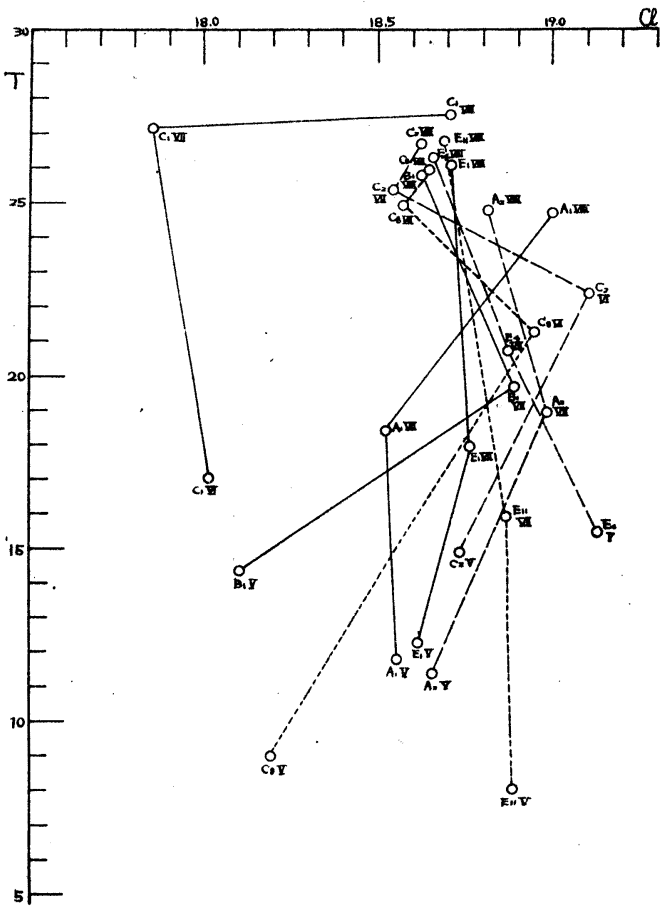

Frig. II. b. Seasenal Chomge o Surpace Viater. (vicutern Preat.)

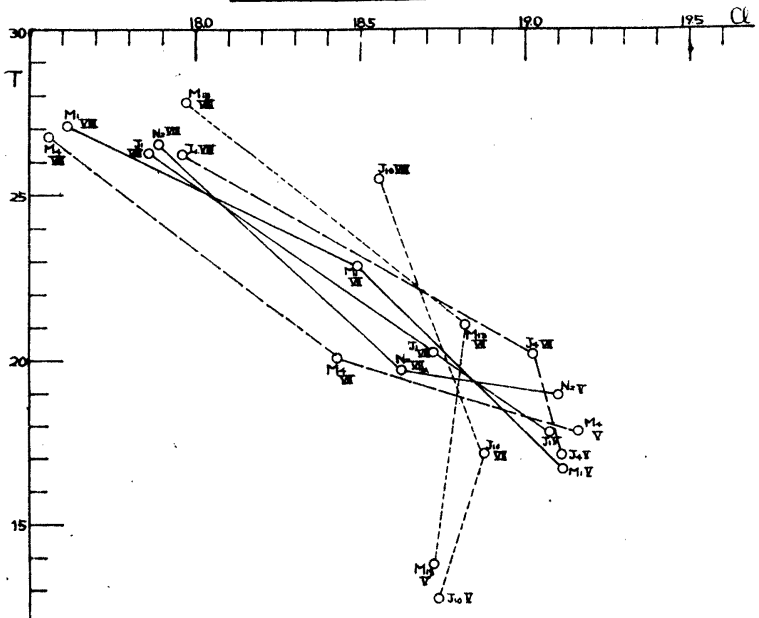




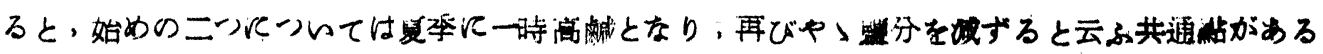

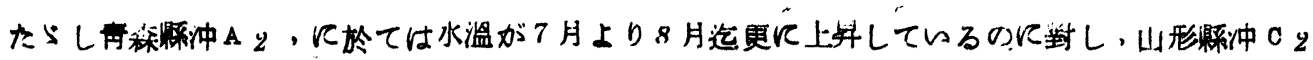

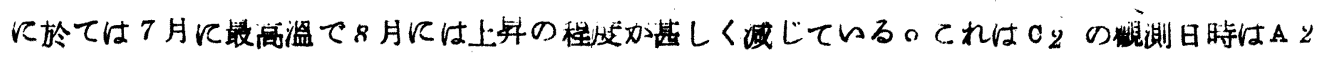

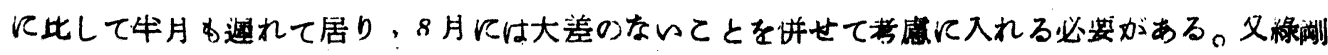

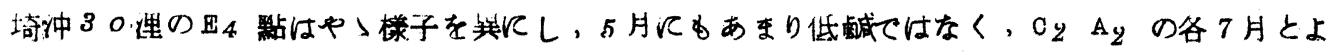

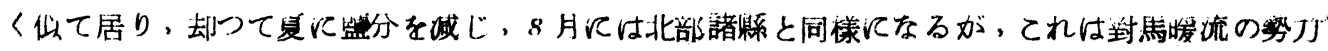

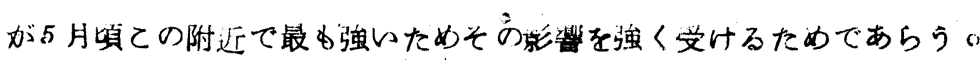

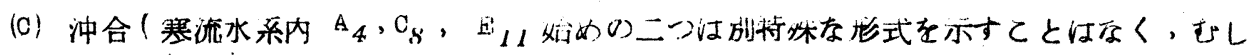

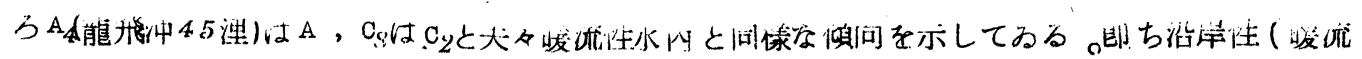

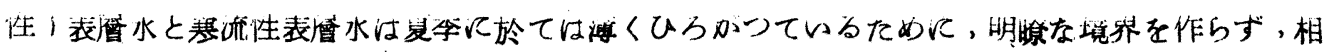

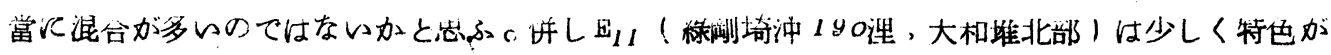

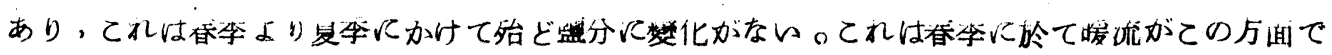

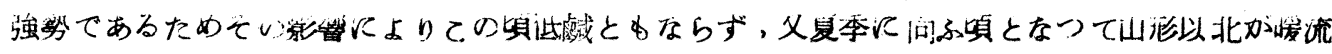

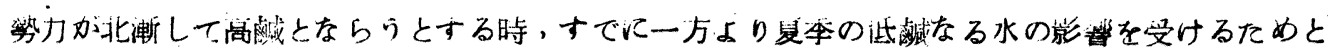
忠はれる。

(D) 北部海域沉於计る表㕌水の變化の概說

以上の結果を棕合して次の如くまとめる。即ち

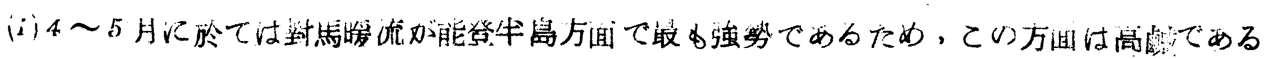

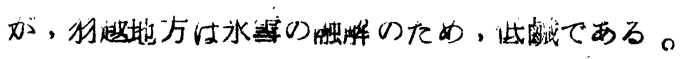

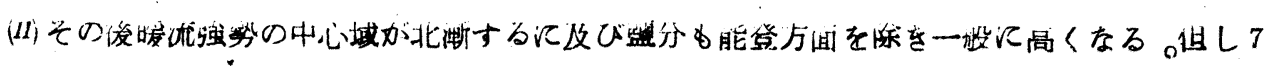

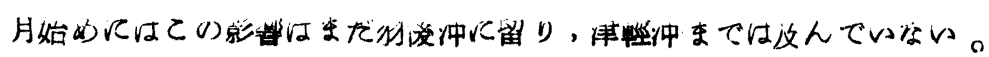

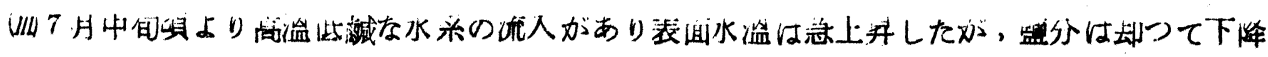

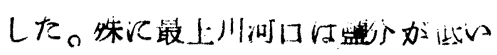

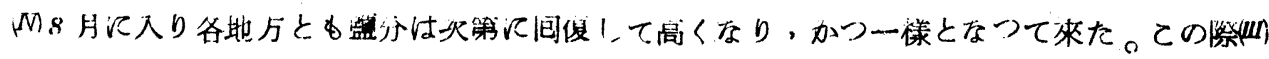

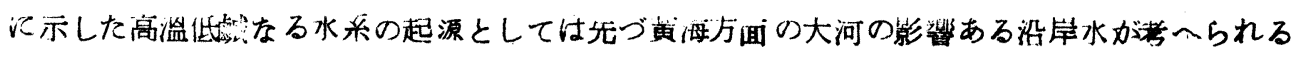

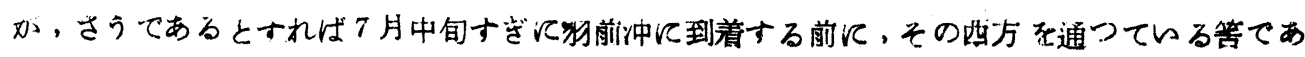

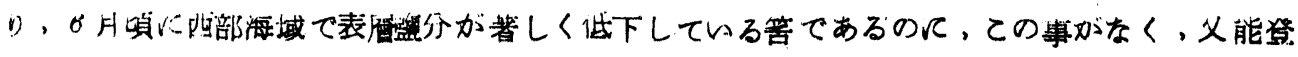

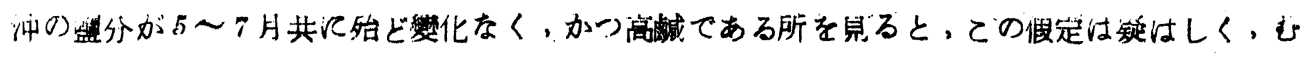

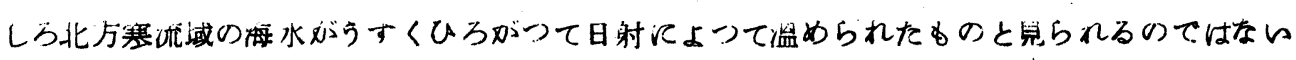
汃と出はれる。

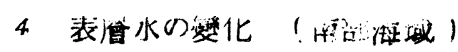




\section{(A) 沿岸近距離}

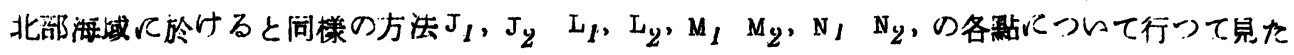

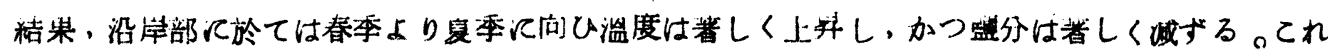

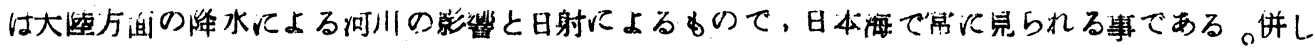

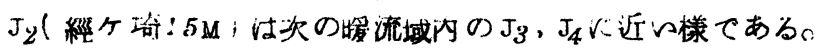

(B) 中趾離暖淿域内

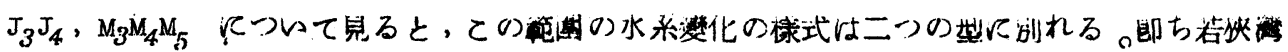

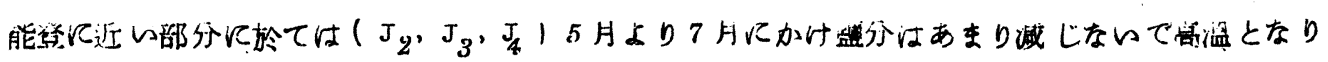

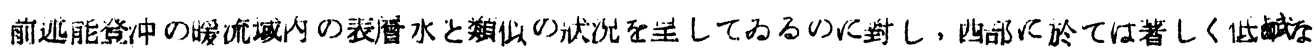

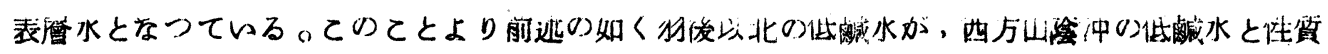
の共るすのではないかと考へられるひである。

(c) 冲合塞水域内 $\left(\mathrm{J}_{10} \mathrm{~J}_{11} \mathrm{M}_{12} \mathrm{M}_{13} \mathrm{~N}_{11}\right)$

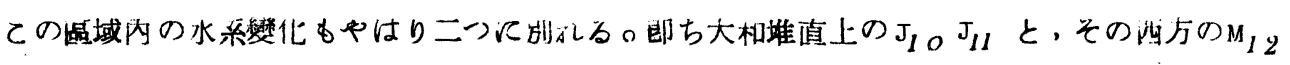

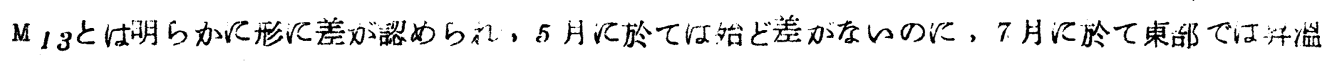

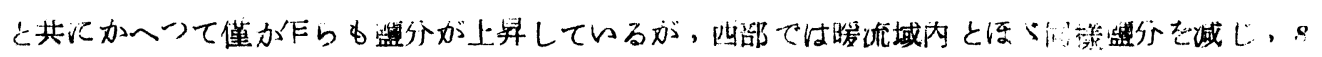

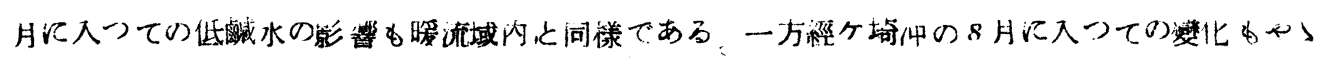

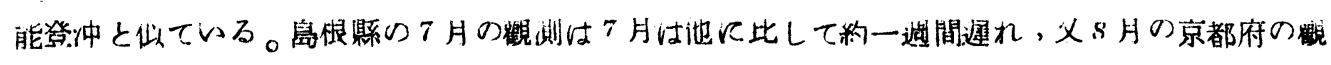

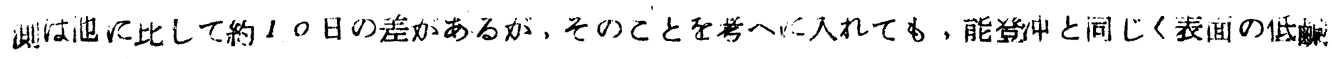

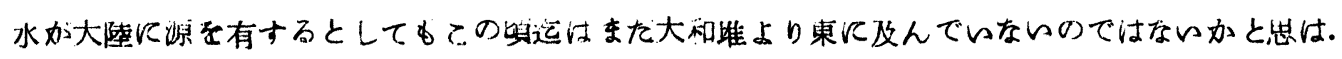
世ל。

Fig. IV. Seasonal Chanae of Subrupace Warm Water.

(D) 以上子棕合ナると

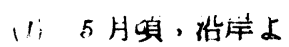
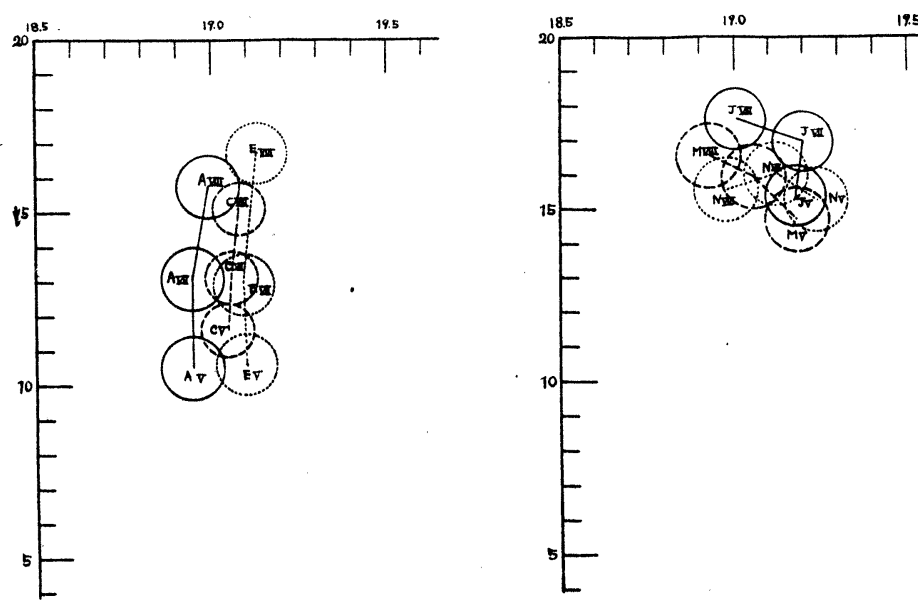

り中此䊒的迄の高盘部 と冲 合の寒流并皮とは朋暸な阔 境を作つていたた。

(ii) 7 月, 沿接及心゙

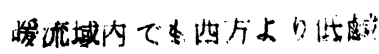
水の都行より啙方はどん どん、下降しがつ猛度は上算 して行つた。しかしての晾

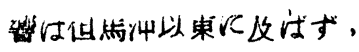




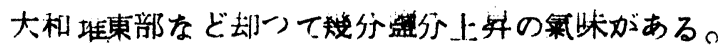

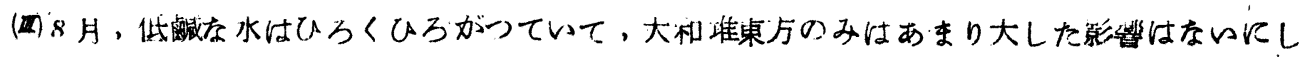

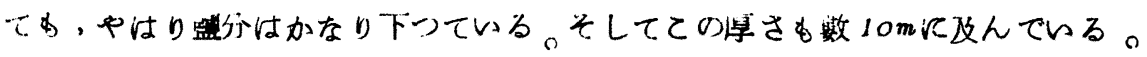

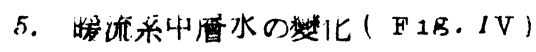

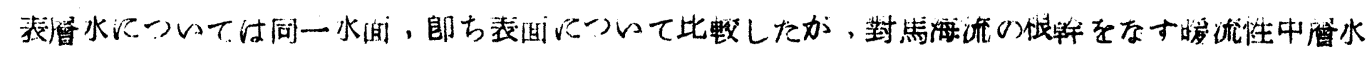

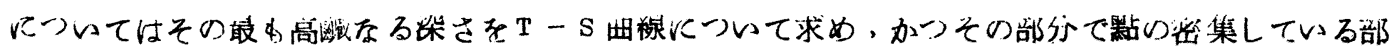

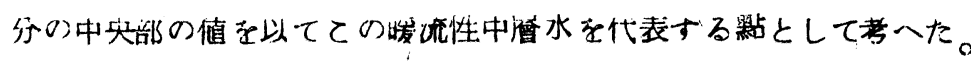

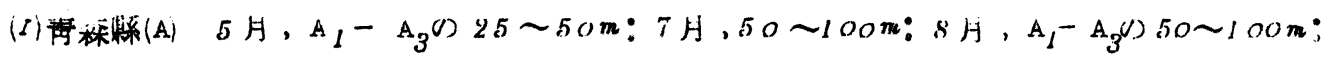

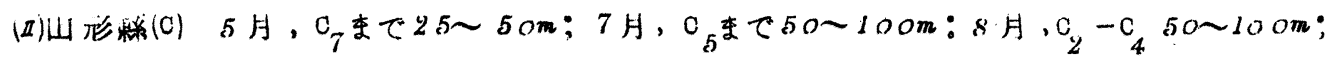

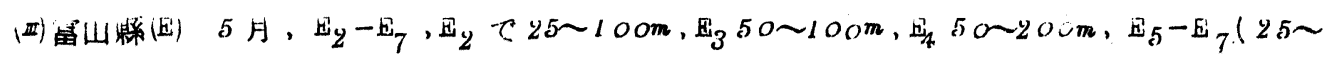

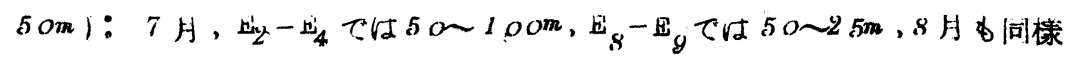

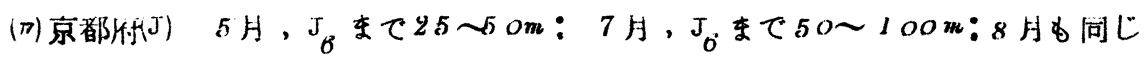

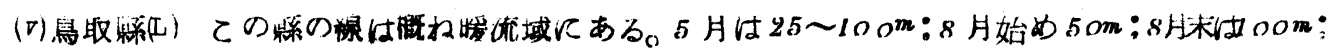

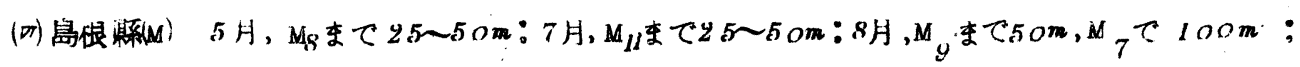

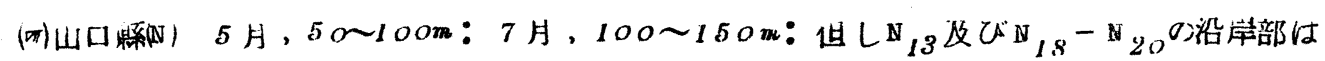
表面の低揇水の混合加ある。8月同樣。

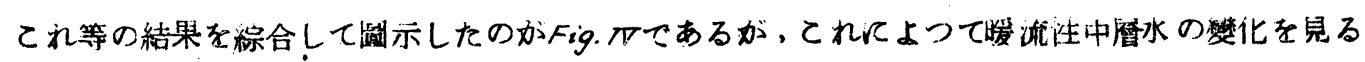

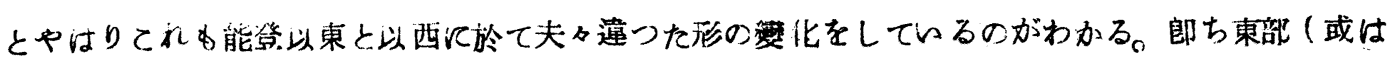

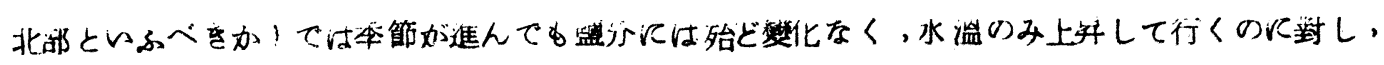

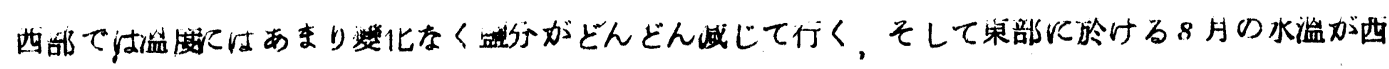

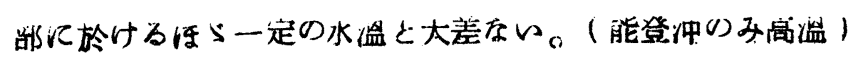

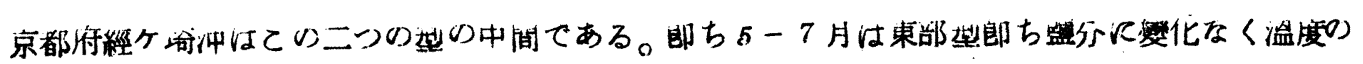

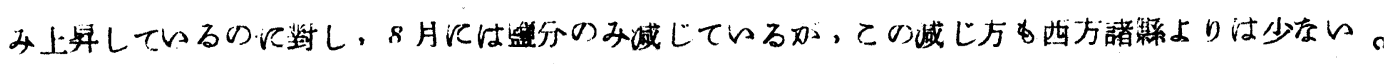

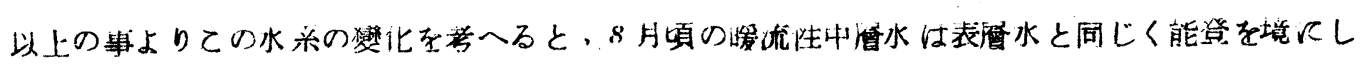

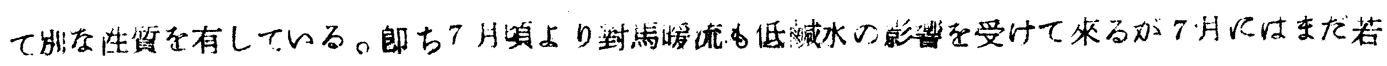

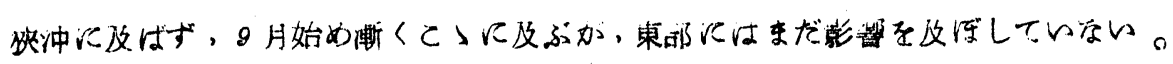

в. 下詹冾水の變论

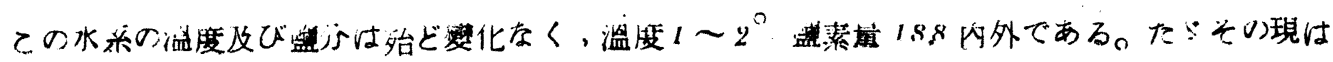

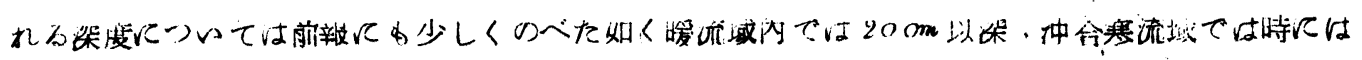

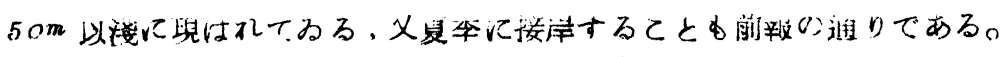

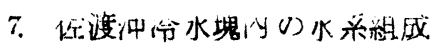




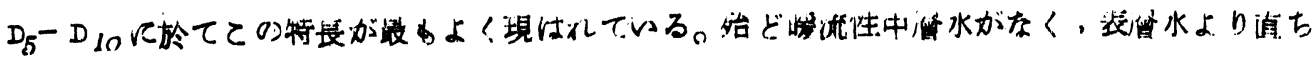

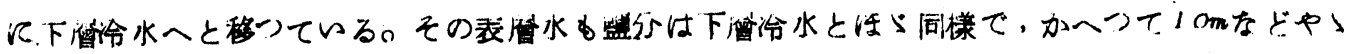
尚毃となてる。

8 绱紫

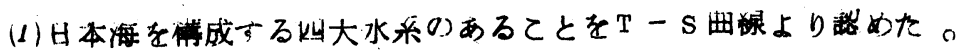

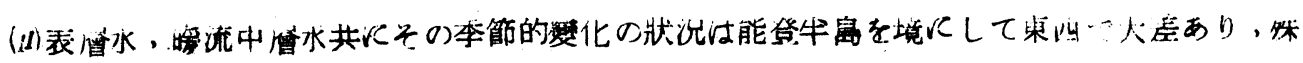

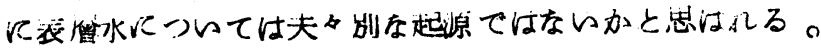

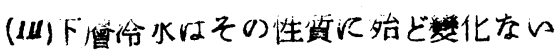

$$
\begin{aligned}
& \text { On the HJarographical Condition of Japan Sea } \\
& \text { in Epring and summer 1949. Part II }
\end{aligned}
$$

By I. Yamanaka, Japan Sea Fy sheries Station

$$
\text { BYNOPSIS }
$$

Ueing thermohaline curves, the water-mass composition of Japan Sea wes discussed about the results of the simultaneous investigations held in spring and summer 1949; and the following facto were ascertained.

(1) There exist four main water massed wh1ch construct Japan Sea, 1.0. (a) surface warm water, (b) aubaurface warm water, (c) surface cold water, and (d) proper cold water in underlayer.

(11) Comparing the veasonal change of surface and subsurface water in the eastern part of Japan soa with that of weatern part, a remarkabledifference 1. recognized, while, in proper cold water, only gilght change 1.s found. 